\title{
Global Imbalances: Origins and Prospects
}

Luis Servén • Ha Nguyen

This paper surveys the academic and policy debate on the origins of global imbalances, their prospects after the global crisis, and their policy implications. A conventional view of global imbalances considers them to primarily result from macroeconomic policies and cyclical forces that cause demand for goods to outstrip supply in the United States and other rich countries and that have the opposite effect in major emerging markets. An alternative view holds that global imbalances are the result of structural distortions and slow-changing factors that primarily affect assets markets. This paper reviews the analytical underpinnings of these two perspectives and the empirical evidence of their respective merits. The paper then assesses the outlook for global imbalances after the crisis, particularly in terms of policy action to reduce their magnitude. Policy intervention is warranted to the extent that the imbalances are driven by welfare-reducing distortions, but in this case, the primary target of policy intervention should be the distortions rather than the imbalances. Finally, the paper examines various forms of international spillovers that may call for multilateral action to limit global imbalances. JEL codes: F32, F36, F42

\section{Introduction}

Since the outbreak of the world financial crisis in 2007, global imbalances-understood as large current account deficits and surpluses of major countries-have taken center stage in the debate over the international economic outlook. Academics have pondered the nature of the imbalances, offering contrasting views about the role of such imbalances at the beginning of the crisis, their potential threat to future global economic stability, and the need for policy measures to "rebalance" the global economy.

Global imbalances are not a new feature of the world economy. Episodes of large and persistent external imbalances in major economies were relatively frequent 
in the 19th and 20th centuries. ${ }^{1}$ The large U.S. current account deficits of the 1980s represent the most recent precedent of the situation observed in the $2000 \mathrm{~s}$. The main distinguishing feature of the current episode concerns the actors and their respective roles. In recent years, emerging economies have exhibited some of the largest surpluses, and advanced economies (notably, the United States) have had the largest deficits. Recent global imbalances involve what has been called an "uphill" flow of capital from poor countries to rich countries. This situation represents a departure from previous episodes and conflicts with the conventional economic theory prediction that developing countries should be net capital importers.

This paper offers a selective survey of the recent literature on global imbalances to shed light on their causes, their likely prospects, and the implications for domestic and multilateral policy action. From an analytical perspective, the paper argues that the various views advanced in the literature regarding the roots of global imbalances encompass two basic perspectives: one that emphasizes cyclical forces and macroeconomic policies affecting global goods markets and another that highlights structural distortions and slow-changing factors affecting global asset markets. The two perspectives are complementary, and both find support in the empirical evidence. However, the recent patterns of global capital flows seem to stress the relevance and the persistence of asset-market forces behind global imbalances.

This paper also reviews the outlook for global imbalances after the crisis, particularly the case for policy action to reduce the magnitude of these imbalances. Theory does not offer clear guidance on what constitutes an "excessive" external imbalance from the single-country perspective, but corrective action may be justified on welfare grounds to the extent that such an action seeks to address the structural and policy-induced distortions reflected in current account gaps.

Proposals for coordinated policy action to contain global imbalances have been advanced by recent academics and multilateral bodies with the rationale that the large current account gaps of individual countries impose costs on the global economy. The paper examines various mechanisms through which such spillovers may accrue, thereby justifying multilateral intervention.

The paper is organized as follows. Section 2 provides a brief retrospective on global imbalances. Section 3 summarizes various views of their causes. Section 4 discusses the outlook for global imbalances after the crisis and the case for national and international policy action to achieve rebalancing. Section 5 concludes the paper.

\section{Global Imbalances in Retrospect}

Despite their recent rise to prominence in the policy debate, global imbalances have been a recurrent phenomenon in the world economy. Under the Gold Standard, for 
example, the United Kingdom consistently funded large deficits of the "emerging markets" of the time - the United States, Canada, Australia, and India. During the 1970s, oil-exporting economies had large surpluses that financed large deficits in developing countries, notably Latin America. In the 1980s, the United States incurred persistent deficits funded by major advanced economies.

The top panel of figure 1 provides a summary of current global account imbalances over the last three decades. It depicts the current account balances of the United States, the European Union (EU), Japan, China, and emerging Asia as well as oil-exporting countries, all measured as percentages of the world gross domestic product (GDP). Two episodes of large imbalances are clearly visible: one in the mid-1980s (already mentioned) and the latest one, of longer duration and larger

Figure 1. Current Account Balances (a) and U.S. Bilateral Current Account Balances (b)

(a)

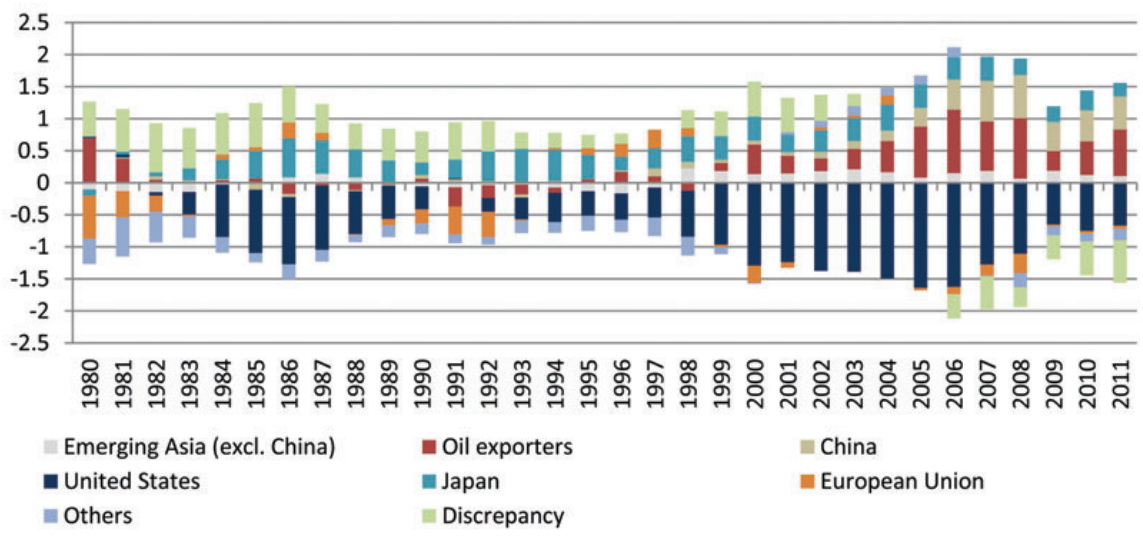

Source: World Economic Outlook

Data for 2010 are preliminary, data for 2011 are projected

(b)

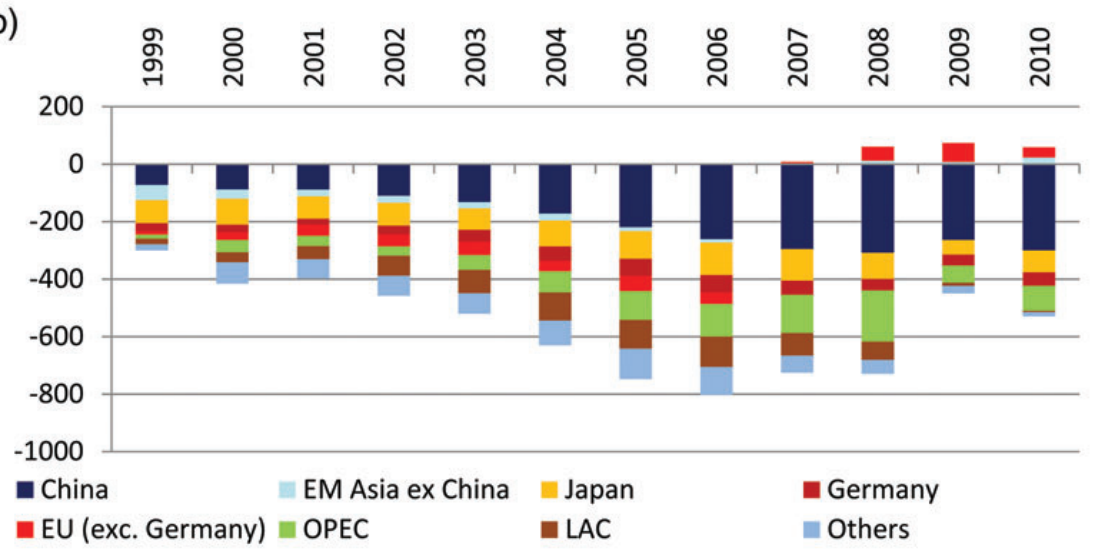

Source: Bureau of Economic Analysis 
magnitude, beginning in the late 1990s. The latter episode peaked in 2006. By the measure shown, however, overall imbalances remained well above historical standards in 2010.

The figure shows that the U.S. current account deficit increased virtually without interruption since the mid-1990s and exceeded 1 percent of the world GDP after 1999. It peaked in 2005 and 2006 at over 1.5 percent of the world GDP. Thereafter, the U.S. external deficit declined below 1 percent of the world GDP in 2008 to 2009, but preliminary estimates suggest that it increased again in 2010. The figure also highlights the key difference between the episodes of the 1980s and 2000s. In the former episode, the main counterparts to the U.S. deficits were provided by the surpluses of Japan and, to a more modest extent, the EU. In contrast, in the 2000s, the surpluses of China and oil-exporting countries gradually became the largest. Since 2005, combined with the persistent surplus of the rest of emerging Asia, global imbalances have largely taken the form of massive capital flows from developing countries to rich countries, particularly the United States. ${ }^{2}$ The bottom panel of figure 1 shows that after 2006, the bilateral deficit with China accounted for the largest portion of the overall current account deficit of the United States. Hence, the popular view of global imbalances as a problem of the United States as compared with China has begun to make sense only in the last few years.

Because the current account surplus is identical to the difference between savings and investment, the trends in these two variables across countries and regions provide information about the sources of changes in their external imbalances. Figure 2 presents the trends in saving and investment rates (as a percentage of the GDP of the country or group of countries in question) from 1991 to the present. As the figure illustrates, in most cases, the largest changes have come from the saving side. In the case of the United States, saving rates fell steadily after 1997 and declined at an accelerating pace in the years preceding the global crisis. As a result, in 2009, the saving rate reached its lowest level in two decades, at approximately 11 percent of the GDP. An examination of the trends in saving and investment reveals that from the end of the 1990s to 2003, a falling saving rate was the principal cause of the increasing external deficits of the United States. After 2003, the swings in the investment rate, which rose steadily prior to the crisis and subsequently collapsed, also contributed significantly to the trends in the current account.

The low saving rate of the United States contrasts with the extremely high levels observed in China, where saving accounts for over 50 percent of the GDP. Since 2000, both saving and investment rates have risen sharply in China, but the former has outpaced the latter. The result has been a major increase in China's current account surplus, which peaked at 10 percent of the GDP in 2007. Closer analysis reveals an increase in China's total saving over the 2000s 
Figure 2. Investment and Saving Rates (\% of GDP)

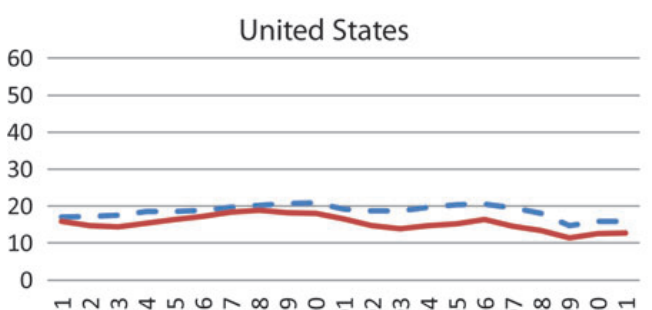

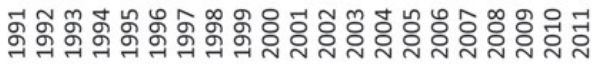

- Investment - Saving

Euro Area

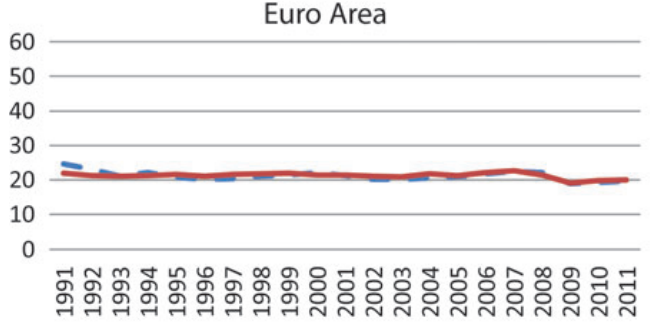

- Investment $\longrightarrow$ Saving

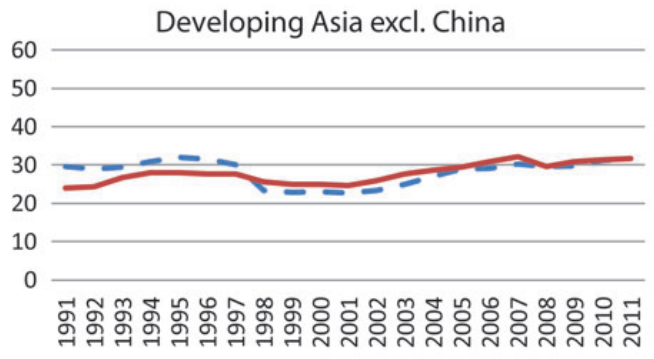

- Investment $\longrightarrow$ Saving
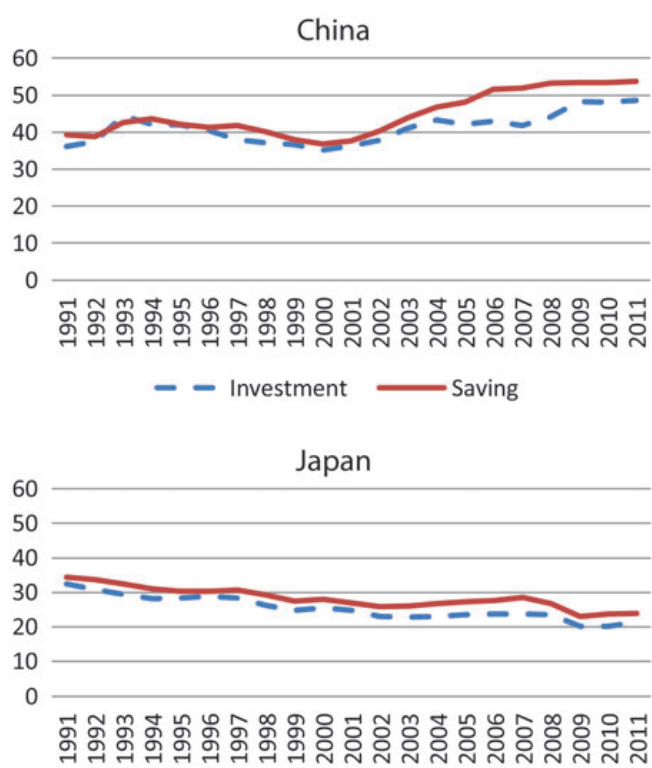

- Investment $\longrightarrow$ Saving

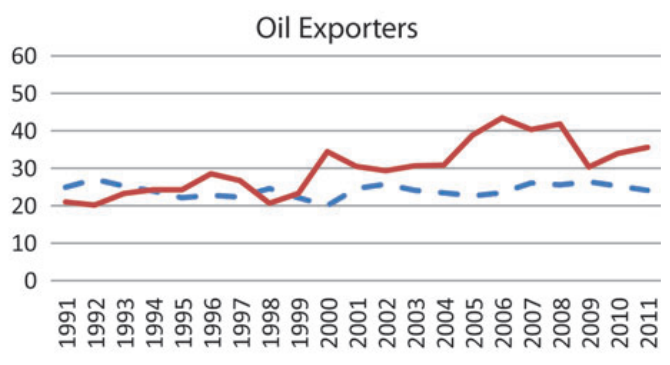

- Investment $\longrightarrow$ Saving

Source: World Economic Outlook - 2011 data are projected

of approximately 17 percent of the GDP. This rise reflects two forces: large increases in household and corporate savings (both near 20 percent of the GDP in recent years) and, to a lesser extent, increases in government saving (Prasad 2011). The contrast between China and the United States is also apparent from the perspective of consumption. U.S. aggregate consumption hovered at about 85 percent of the GDP in the 1990s and 2000s, with a slightly increasing trend. China's consumption ratio was much lower in the 1990s, under 65 percent, but it declined over the 2000s to a low of just 47 percent in 2008.

In industrial countries other than the United States, saving and investment rates have undergone changes that are more modest. In the EU, these rates have remained 
roughly stable, at slightly above 20 percent of the GDP. In Japan, both saving and investment rates followed a downward trend over the 1990s but stabilized in the last decade, when the current account continued to show a steady surplus.

Investment rates fell sharply in emerging Asia following the 1997 crisis, leading to large current account surpluses in the early 2000s that subsequently declined as investment recovered. ${ }^{3}$

Finally, saving rates showed a steep increase in commodity-exporting countries because of the persistent rise in world commodity prices. Although this trend was interrupted in 2009 by the sharp decrease in commodity prices induced by the global crisis, rising saving rates led to widening current account surpluses, especially among oil exporters. However, high saving rates resumed as commodity prices recovered, and the combined current account surplus of oil exporters was projected to exceed 10 percent of their GDP in 2011.

\section{The Origins of Global Imbalances}

The trends in saving and investment provide an accounting decomposition of the observed changes in current account balances across the world, but they do not identify the underlying causes. The sources of global imbalances have attracted considerable interest from academics and policy analysts, who have offered different views stressing a variety of causal factors. We will organize these views into two polar extremes, defined by their emphasis on conventional, cyclical macroeconomic forces (e.g., technological shocks, fiscal and monetary policies) relative to the emphasis on slow-changing forces, such as institutional development and deep-seated market or policy-induced distortions.

One view considers imbalances a reflection of asynchronous fluctuations in spending across the world. For want of a better term, we label this the "disequilibrium view" because it considers imbalances to be a temporary (and hence unsustainable) phenomenon pending correction. However, this designation does not imply that imbalances reflect a failure of goods or asset markets to clear or a failure of consumers and investors to act in their own best interests. The second view takes the opposite perspective: global imbalances reflect deep-seated structural forces and may be self-sustaining for an extended period. We label this perspective the "equilibrium view."

These contrasting perspectives also differ in their relative emphasis on goods and assets markets. The former view focuses primarily on goods markets and takes a conventional current-account perspective, in which global imbalances results primarily from international asymmetries in the balance between demand and supply for (tradable) goods. The latter view, in contrast, centers on the capital account and stresses international asymmetries in the supply and demand for international assets. 
In reality, the distinction between cyclical and structural factors is less than clear. Both sets of factors have likely influenced the recent episode of global imbalances. Thus, to a large extent, the two views should be regarded as mutually complementary rather than competing. However, their different emphases lead to somewhat different policy implications. The first view suggests the need for standard macroeconomic adjustment of aggregate expenditure and exchange rates. The second view calls for medium-term correction of underlying structural distortions. Next, we review the major aspects of both perspectives. ${ }^{4}$

\section{Standard Macroeconomic Forces: The "Disequilibrium" View}

Conventional demand/ supply-based explanations of global imbalances have focused primarily on the macroeconomic factors responsible for the decline in the U.S. aggregate saving rates described above. This phenomenon reflected both declining public saving and, especially, declining private saving. The roles of real and financial shocks as well as macroeconomic policies have received considerable attention.

Some observers have argued that the declining savings and rising deficits of the United States in the 1990s were largely driven by acceleration in productivity growth, attributable to the information and communication technology revolution (e.g., Cova et al. 2008). In this conventional view, the anticipation of higher future growth would have prompted increased spending and deficits in the United States in a manner consistent with optimal forward-looking behavior (Engel and Rogers 2006). However, the persistent decline in private saving, particularly in the 2000s, was related to a financial cycle of unusual size, characterized by rapid growth of credit to consumers and escalating asset prices, particularly in housing. The credit and asset boom was propelled, in part, by persistently low interest rates. Some scholars (e.g., Taylor 2009) blamed these rates on an excessively expansionary monetary policy that encouraged excessive risk taking by banks and other financial institutions. Households responded by increasing consumption spending from their newfound wealth. Indeed, the asset boom resulted in a significant increase in the wealth-income ratio of the United States despite the low saving rates (Bosworth and Collins 2010). In turn, expansionary U.S. fiscal policy led to reduced public saving, which contributed to the decline in aggregate saving and the current account deficit. However, the precise extent of this effect remains disputed. Available empirical estimates suggest that the impact of public deficits on external deficits is far less than one for one (e.g., Chinn and Ito 2007).

In the conventional view, these shifts in aggregate expenditure and the external imbalances to which they contributed cannot be sustained. This conclusion follows from the routine application of the intertemporal budget constraint. Excluding the possibility of default and abstracting from capital gains and losses 
on external assets and liabilities, the intertemporal budget constraint of a country dictates that its net liability position against the rest of the world at any given time cannot exceed the present value of its future trade surpluses.

In principle, however, a country can continue to run current account deficits for an extended period of time as long as it is capable of running sufficiently large trade surpluses in the future. This may be the case for developing countries that borrow to invest and accumulate capital and repay their debts once they reach a higher stage of development (e.g., Kraay et al. 2005). Likewise, an advanced country could run current account deficits if, in the future, it is expected to grow faster than the rest of the world. In effect, the advanced country finances its consumption by borrowing against its future income (as argued by Engel and Rogers 2006 for the United States).

In any case, the U.S. net foreign asset position has undergone a steep decline. The United States moved from a creditor position amounting to 10 percent of its GDP at the beginning of the 1980s to a debtor position close to 25 percent of its GDP in 2009. In absolute terms, this debtor position is the largest in the world. Reversal of this trend demands a change in the sign of the U.S. trade balance, which, in turn, requires a depreciation of the dollar to increase net exports. In an extreme but theoretically possible (if somewhat alarming) scenario, these adjustments may occur in the form of a sudden stop of capital flows into the United States and a collapse of the dollar (e.g., Mussa 2004; Roubini 2008).

In fact, the dollar has depreciated substantially in real (i.e., purchasing power) terms since 2002, but subsequent U.S. external deficits have remained quite large. This phenomenon suggests that further real-dollar depreciation may be forthcoming. The required magnitude of the trade-balance correction and the depreciation necessary to achieve it have been the object of detailed analysis in numerous studies (see, e.g., Obstfeld and Rogoff 2007, 2009 and Méjean, Rabanal and Sandri 2011).

Most of these studies follow convention in assuming that the U.S. external imbalance demands a real adjustment - a reversal of the trade deficit. However, recent literature has argued that financial adjustment can also play an important role. The change in the net foreign asset position of a country consists of (1) the trade balance and (2) the total return on its net foreign assets. The latter component includes not only the yields on foreign assets and liabilities, which are included in the current account, but also the capital gains and losses arising from changes in their prices, which are omitted from the current account. Because of this important omission, the time path of the net foreign asset position is no longer determined by the current account balance alone.

Financial adjustment had received little attention until a few years ago, but new research has stressed its quantitative importance in the case of the United States for two reasons. The first reason is the difference between the yields on U.S. assets and liabilities. A number of observers find that foreign assets held by 
U.S. investors yield higher returns than U.S. assets held by foreign investors (Hausmann and Sturzenegger 2006; Gourinchas and Rey 2007a, b; Forbes 2010). Although seemingly counterintuitive, this situation makes it possible for the United States to earn positive returns on its foreign asset portfolio even if the country's net asset position is negative - a phenomenon that appears to be unique to the United States (Habib 2010).

The second reason is related to the effect of changes in the dollar exchange rate on the U.S. asset position. The key here is that a real depreciation of the dollar generates a wealth transfer in favor of the United States because its external liabilities are denominated in dollars whereas its assets are denominated in other currencies (typically those of the issuing countries). This is exactly the reverse of the usual situation in emerging markets indebted in foreign currency when their exchange rate undergoes a real depreciation.

Thus, dollar depreciation has a double effect on the U.S. external asset position. On the one hand, it generates real adjustment through an improving trade account balance. On the other hand, it generates financial adjustment through capital gains (i.e., losses for the rest of the world). The important insight here is that assessments of the trade surplus required to put the external position of the United States on a sustainable trajectory can easily overstate the extent of the necessary policy correction if they do not take this second effect into consideration.

The empirical magnitude of financial adjustment remains controversial, particularly because of the lack of detailed data on the yields and prices of international assets and liabilities (see, e.g., Gourinchas and Rey 2007a; Curcuru, Thomas and Warnock 2008; and Gourinchas, Rey and Govillot 2010). However, the massive increase in cross-border asset holdings over the last two decades logically implies that valuation effects must have become more important. Indeed, there is evidence that, in recent years, valuation changes have dominated the observed changes in countries' net foreign asset positions, dwarfing the effects of current account imbalances (Devereux and Sutherland 2010).

Figure 3 provides information on the growing importance of such valuation effects in the case of the United States. The graph shows the trends in the U.S. current account balance and the valuation effects due to asset price movements and exchange rate changes over the last two decades, with both expressed as percentages of GDP. The change in the net foreign-asset position is given by the sum of the two series.

The figure shows that the United States has enjoyed large valuation gains since 2002, which peaked at 8 percent of its GDP in 2005-an order of magnitude similar to that of the current account deficits of those years. Two main factors were at play. The first factor was the relative decline in U.S. stock market prices since 2000, which generated capital losses for foreign investors (Kraay and Ventura 2005). The second factor was the depreciation of the dollar after 2002, which 
Figure 3. U.S. Current Account Balance and Valuation Effects (Percent of GDP)

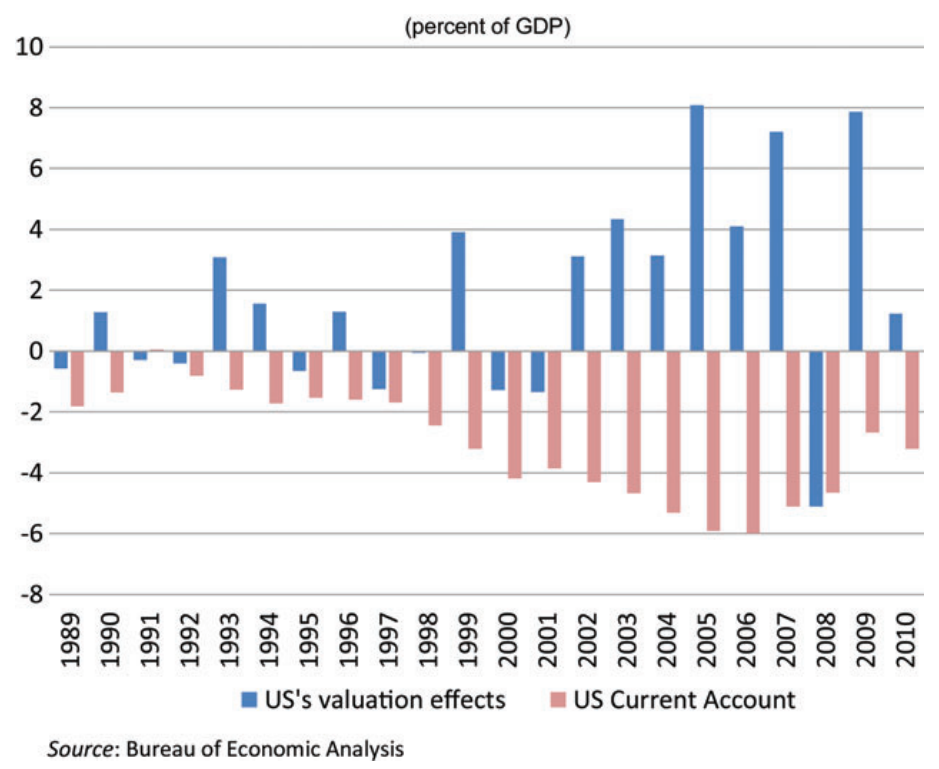

allowed the U.S. net foreign asset position to increase from 2003 to 2007 despite the record-high current account deficits of those years. In 2008, however, the United States suffered a large negative valuation effect because of international investors' "flight to quality," which caused an appreciation of U.S. assets and the dollar. ${ }^{5}$ However, valuation effects turned in favor of the United States again in 2009. Looking forward, the implication is that the depreciation of the dollar required to ensure the sustainability of the external position of the United States is likely to be much more modest than what would be necessary if external adjustment had to occur only from the trade balance. Indeed, over the last twenty years, the correlation between the current account balance and the change in net foreign assets in the United States has been only 0.15, which implies that the current account plays a relatively minor role in shaping the country's net foreign asset position.

\section{Structural Factors: The "Equilibrium" View}

In contrast to the view of global imbalances as driven by international shifts in aggregate demand for goods, the "equilibrium view" traces them to structural factors that have caused a shift in the international pattern of excess demand for assets. These structural factors change only gradually, implying that global imbalances may be sustained for a long time. 
Admittedly, this is a very broad generalization, in part because it encompasses a variety of views on the ultimate determinants of global imbalances. However, one feature common to all of these views is the emphasis on assets markets and the capital account, in contrast to the analytical emphasis placed on the supply and demand for goods and the current account in the preceding section. Consider first the supply of international assets. An influential view holds that global imbalances largely reflect the differential ability of advanced and emerging countries to supply high-quality assets for international savers (e.g., Caballero, Fahri and Gourinchas 2008a, b). In particular, the financial underdevelopment of emerging countries prevents them from generating financial instruments that are attractive to their savers for two simple reasons: the yields on local assets are too volatile, and they bear expropriation risks, as exemplified by the financial crises of the 1990s. The result is that international savers tilt their portfolios toward the assets of countries with more advanced financial markets, particularly the United States. A growth acceleration in emerging countries (or an oil price boom) that increases their wealth and saving - the forces behind the so-called "global saving glut" (Bernanke 2005) -leads them to expand their holdings of U.S. assets. ${ }^{6}$ This expansion is achieved through U.S. current account deficits that raise the volume of U.S. assets available to international investors. This process can persist as long as its driving force- the lagging development of financial markets in emerging countries-remains unchanged. As a result, capital flows "uphill," from poor countries to rich countries.

An analogous line of reasoning stresses international asymmetries in the demand for assets, rather than their supply. These asymmetries may be driven by the response of individual savers to idiosyncratic risk. Underdeveloped financial markets in emerging countries offer individuals few options to hedge income shocks or borrow against future income, and these few options force savers to raise their precautionary wealth accumulation to ward off idiosyncratic income risk (Mendoza, Quadrini and Ríos-Rull 2009. This mechanism affects not only households but also entrepreneurs facing risky investment projects (Angeletos 2007; Sandri 2010). Similarly, the underdevelopment of the social-protection system in emerging countries encourages precautionary wealth accumulation against unemployment or retirement risk (Carroll and Jeanne 2009).

Other things equal, the result is that savers in emerging countries tend to save more than those in industrialized countries. Financial integration between emerging economies with underdeveloped financial markets and weak social protection systems and rich countries with more advanced financial markets and socialprotection systems leads to a global equilibrium in which the former countries acquire a creditor position whereas the latter countries are net debtors. As long as the gap between both sets of countries, in terms of the degree of development 
of financial markets or social-protection systems, remains unaltered, global imbalances and uphill capital flows can persist.

These theoretical arguments seem consistent with the empirical observation that, other things equal, during the 2000s, private investors from emerging countries with less-developed financial markets typically allocated larger shares of their portfolios to U.S. assets (Forbes 2010). Related to this observation, many analysts attribute China's high levels of corporate saving to the limited development of domestic financial markets, which leads firms to fund the bulk of their investment through retained earnings. However, the weak governance framework of large state-owned enterprises, which faced no obligation to distribute dividends until recently, has undoubtedly played a role as well. The empirical evidence also suggests that Chinese households' limited access to borrowing in a context of rising income risk (following the pro-market reforms of the 1990s) and the weakening of the social protection system over the same period are key factors in the rising levels of household saving in China (Chamon, Liu and Prasad 2010; Chamon and Prasad 2010). Likewise, rising public saving in the 2000s was largely driven by the decline, relative to GDP, of net government transfers, notably pension and social insurance payments.

Deliberate policy choices by national economic authorities may be another factor in international asymmetries in the demand for assets. Policy makers may decide to engage in foreign asset hoarding to support a "new mercantilist" development strategy based on export-led growth. This objective is facilitated by an undervalued real exchange rate and foreign asset accumulation to preserve export competitiveness. Historically, Japan and Germany have followed the export-led growth model. This model has been adopted more recently by a number of emerging markets, particularly in East Asia, with China prominently among them. ${ }^{7}$ Indeed, some observers have argued that global imbalances arise primarily from the export-led growth strategy of Asian economies (e.g., Adams and Park 2009). This development strategy defines the so-called "Bretton Woods II" system (Dooley, Folkerts-Landau and Garber 2004), in which emerging Asian countries play the role of producers of last resort, and advanced countries-led by the United States-are the consumers of last resort whose deficits are financed by capital inflows from Asia. ${ }^{8}$ Proponents of this view claim that Bretton Woods II can remain in operation indefinitely as long as emerging Asia maintains the export-led strategy and is willing to accumulate claims on the United States and other advanced countries.

The logic of this strategy is that, under appropriate circumstances (related mainly to the presence of strong positive externalities in the production of tradable goods), the mercantilist development model may succeed in accelerating structural transformation and economic growth. In this vein, Rodrik (2008) offers suggestive evidence of a positive correlation between exchange rate 
undervaluation and economic growth. Nevertheless, the merits of the export-led growth strategy from the welfare standpoint are not obvious because the largescale accumulation of external (and, typically, low-yield) assets involves major opportunity costs in terms of foregone consumption (see Korinek and Servén 2010 for details). Policy makers' ability to sustain the export-led strategy may be threatened by its diminishing growth returns as positive externalities become exhausted, by society's rising demands for higher consumption, and by the increased ability of private investors to offset the authorities' attempts at continued foreign asset hoarding, brought about by deepening financial integration (Eichengreen 2004).

Emerging-market policy makers may also engage in foreign asset hoarding as a precautionary policy. In the absence of mechanisms for international diversification of aggregate risk, emerging countries integrated into the global financial system must resort to self-insurance against external shocks, such as disruptions of international capital flows of the kind observed in the crises of Asia and Russia in the 1990s. Thus, emerging countries accumulate external assets-preferably short-term instruments - upon which they can draw in the event of a "sudden stop." Unless the global financial system generates new mechanisms to hedge these risks, this precautionary foreign asset accumulation is unlikely to cease. ${ }^{9}$

Empirically, the massive accumulation of international reserves by emerging economies during the last decade suggests that the policy of foreign asset hoarding has played an important role. Figure 4 depicts the foreign reserve holdings of industrial and emerging countries since the early 1990s. Between 1998 and 2010, the reserve holdings of the latter, measured in constant prices, increased six-fold, whereas those of industrial countries rose less than 100 percent. As a result, the volume of international reserves held by emerging markets at present greatly exceeds that of industrial countries. Indeed, at the end of 2010, China's foreign reserve stock exceeded that of all industrial countries combined. The rest of emerging Asia has also dramatically increased its reserve holdings. However, the phenomenon is not confined to Asia; Latin American economies and oilexporting countries have also accumulated large volumes of international reserves over the last decade.

Nevertheless, the question remains whether reserve accumulation was primarily driven by caution against the volatility of international capital flows or by the pursuit of competitive exchange rates. Disentangling the relative importance of these two factors is not an easy task; their respective roles are likely to vary across countries and over time. Aizenman and Lee (2007) attempt to address this question in a regression framework using data from 49 countries for 1980 to 2000. They conclude that both motives were at work during that period but that the precautionary saving motive was more important. In line with this finding, Durdu, Mendoza, and Terrones (2007) show that foreign reserve holdings of the countries that suffered "sudden stops" in the 1990s and 2000s were substantially 
Figure 4. Foreign Exchange Reserves of Industrial and Emerging Countries (Billions, constant 2000 US\$)
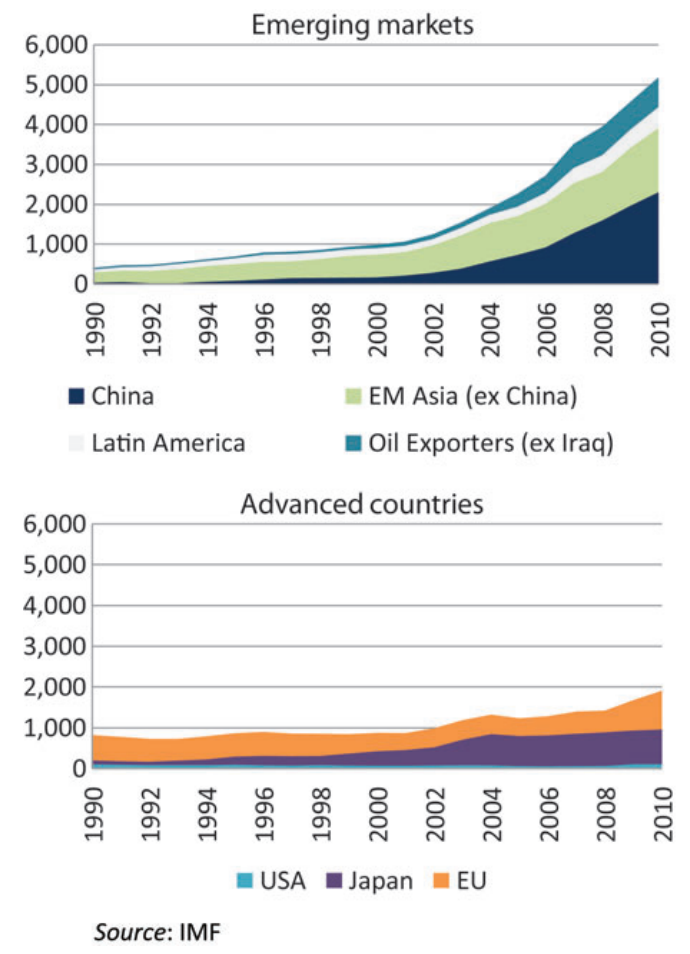

larger after the sudden stop than before in all but one country. The change was quite significant - on average, they doubled. This evidence seems to lend support to the precautionary motive. However, there are clear indications that in a number of emerging countries, notably in Asia, the reserve buildup has been too large to be justified by the precautionary motive alone (see, e.g., Jeanne and Ranciere 2011). Figure 5 corroborates this view. In all emerging markets shown in the figure, foreign reserves amply exceeded short-term external debt in 2009, in most cases by a huge margin-over tenfold in China and fivefold or more in a number of other countries. This finding suggests that mercantilist reasons for foreign asset hoarding likely played a prominent role in a number of countries, especially China.

Although this evidence strongly suggests that deliberate policy choices were a major factor in the accumulation of foreign assets by emerging markets, it does not necessarily imply that they were the only factor. If this had been the case, capital inflows from emerging markets to the United States would likely reflect a dominant role of official flows over private flows. The available information, 
Figure 5. Emerging Market Foreign Reserves (As \% of Short-term Debt)

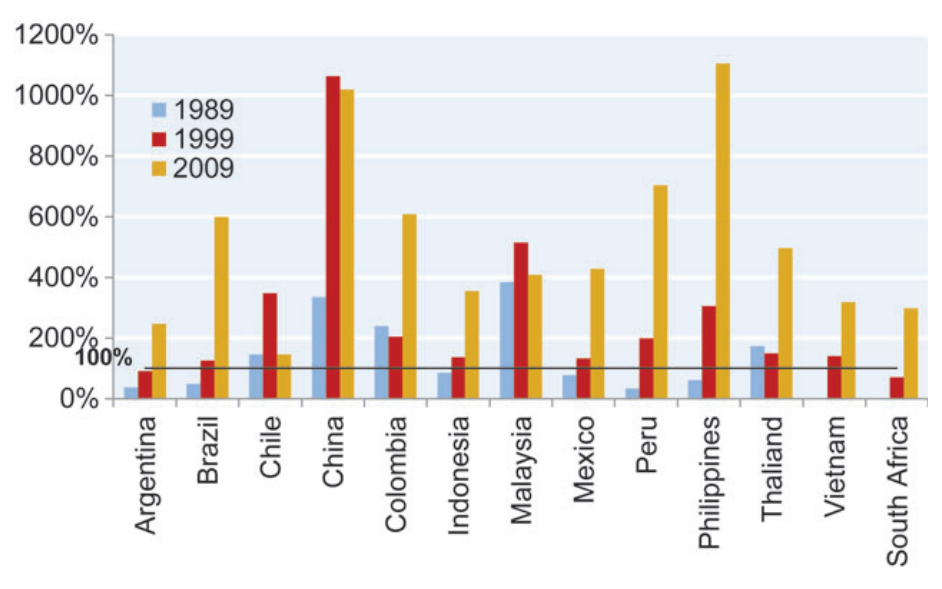

Source: World Development Indicators

shown in figure 6 , should be taken with some caution, but overall, it suggests a mixed picture. Purchases of U.S. assets by official entities (central banks and government bodies) from emerging markets in Latin America, Asia, and the Middle East became increasingly large in the 2000s. Indeed, after the onset of the crisis in 2007, such purchases became the sole source of inflows from these countries. However, over the decade as a whole, the total volume of emerging-market official inflows to the United States was roughly on par with that of private inflows, and the latter actually exceeded the former in the precrisis years from 2000 to $2007 .^{10}$

Finally, the above discussion highlights the role of a variety of forces that contributed to increasing emerging countries' excess demand for quality assets. However, it is important to keep in mind the effect of financial innovation in advanced countries within a context of lagging, and even weakening, regulation of the financial system, particularly the United States. These factors contributed to the credit boom and the housing bubble, which, as many observers have noted, were key aspects of the collapse of private saving and the widening of the U.S. current account deficit. Indeed, some empirical exercises suggest that the rise in aggregate expenditure derived from the private sector's bubble-driven wealth increase and enhanced access to credit may quantitatively explain the bulk of the U.S. external imbalances of the 2000s (Laibson and Mollerstrom 2010). From a political-economy perspective, Rajan (2010) has argued that the hands-off regulatory stance at the root of the credit boom can be partly viewed as a response to the longstanding increase in U.S. income inequality. According to this view, given the limited political support for redistributive policies, enhanced access to cheap 
Figure 6. Gross Capital Inflows into the U.S. from Emerging Markets (US\$ Billions)

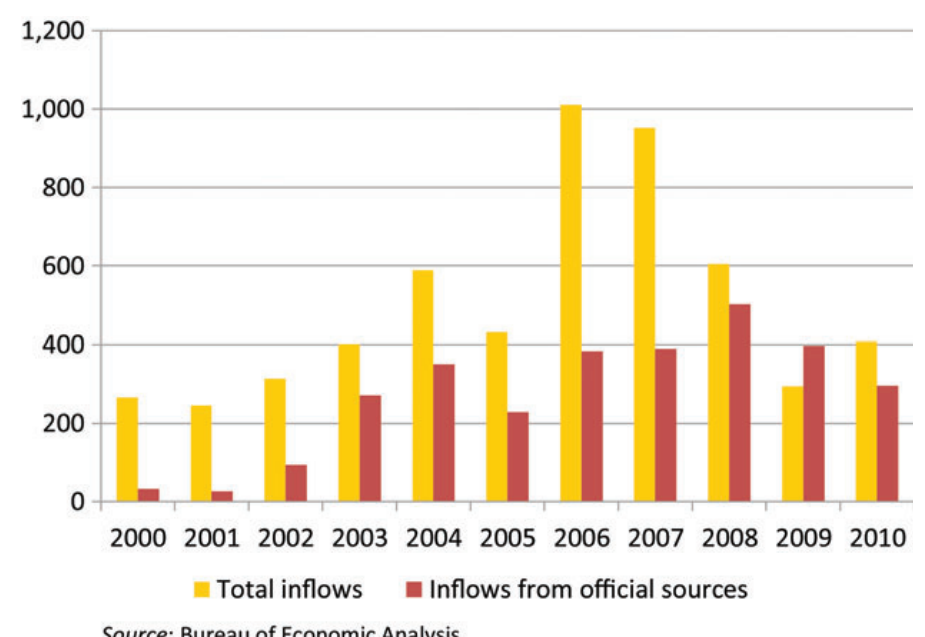

credit would have offered an alternative way to sustain consumption growth by large segments of the population despite their stagnant or diminishing real incomes.

\section{Future of Global Imbalances}

Evaluating competing views about the causes of global imbalances enables us to better assess the outlook for global imbalances after the crisis, particularly in terms of the need for policy action to reduce their magnitude. We next provide an overview of the imbalances after the global crisis, and we then examine various forms of international spillovers that may call for multilateral action to limit global imbalances. The key principle is that policy intervention is warranted to the extent that the imbalances are driven by welfare-reducing distortions, but in such case, the primary target of the intervention should be the distortions rather than the imbalances themselves.

\section{Global Imbalances after the Global Crisis}

It is unquestionable that global imbalances have narrowed since the onset of the global crisis. The U.S. current account deficit, measured as a proportion of the GDP, has declined sharply, from 6.1 percent of the GDP in the second quarter of 2006 to 3.5 percent at the end of 2010. On a global scale, the crisis initially led 
to an abrupt fall of international capital flows and to the collapse of world trade and oil and commodity prices. The latter, in turn, caused a sharp reduction in the surplus of oil-exporting countries. China's surplus also declined under the additional pressure of a major fiscal stimulus package deployed by the authorities in response to the crisis.

Is this the beginning of the end for global imbalances? It is difficult to provide a conclusive answer. As the preceding section suggests, the future of global imbalances depends on a constellation of real and financial forces whose evolution is difficult to predict. On the one hand, to the extent that their key determinants remain largely unchanged, the imbalances may resume after the crisis. Indeed, figure 1a shows that the U.S. current account deficit widened slightly in 2010. On the other hand, prospective and ongoing policy changes and structural reforms, summarized below, could lead to a sustained narrowing of imbalances.

In this regard, it is important to emphasize that the crisis did not involve a "sudden stop" of capital flows to the United States, which could have given rise to a disorderly unraveling of global imbalances and an abrupt depreciation of the dollar. Instead of the depreciation that many had predicted, the dollar experienced an initial appreciation as a result of international investors' flight to safety, which led them to shelter in low-risk U.S. Treasury debt at the expense of risky assets, from corporate debt to emerging-market assets. In effect, the dollar became the reserve currency of last resort, and the U.S. government became the borrower of last resort (Gorinachas, Rey and Govillot 2010). This "safe haven" effect of U.S. assets has recently resurfaced in the context of the Eurozone's sovereign debt turmoil.

In the aftermath of the global crash, there are some indications that the precrisis pattern of capital flows to the United States may be resuming. This pattern is illustrated in figure 7, which updates the information in De la Torre, Schmukler, and Servén (2009). The flows shown in the figure comprise long-term financial instruments only, but their time profile is revealing. The top line captures the inflow of capital from nonresident investors. Until 2008, it is always positive, reflecting an upward trend interrupted in late 2006. The bottom line captures the inflow of capital from resident investors. For the most part, these flows take negative values, indicating capital outflows by U.S. investors. However, at the onset of the subprime turmoil in mid-2007, these patterns changed abruptly: capital inflows from nonresidents collapsed, and outflows from residents changed sign, reflecting capital repatriation by residents to stem losses in domestic markets or to seek safe haven from the global turbulence. Since 2009, however, the data reveal an incipient or emerging return to the precrisis pattern: both capital inflows of foreign investors and outflows of resident investors appear to return to their earlier trends. This finding indicates the persistence of the deep determinants of global imbalances and suggests that they may not disappear anytime soon. 
Figure 7. Gross Capital Inflows to the U.S. (in long-term securities) (US\$ Billions)

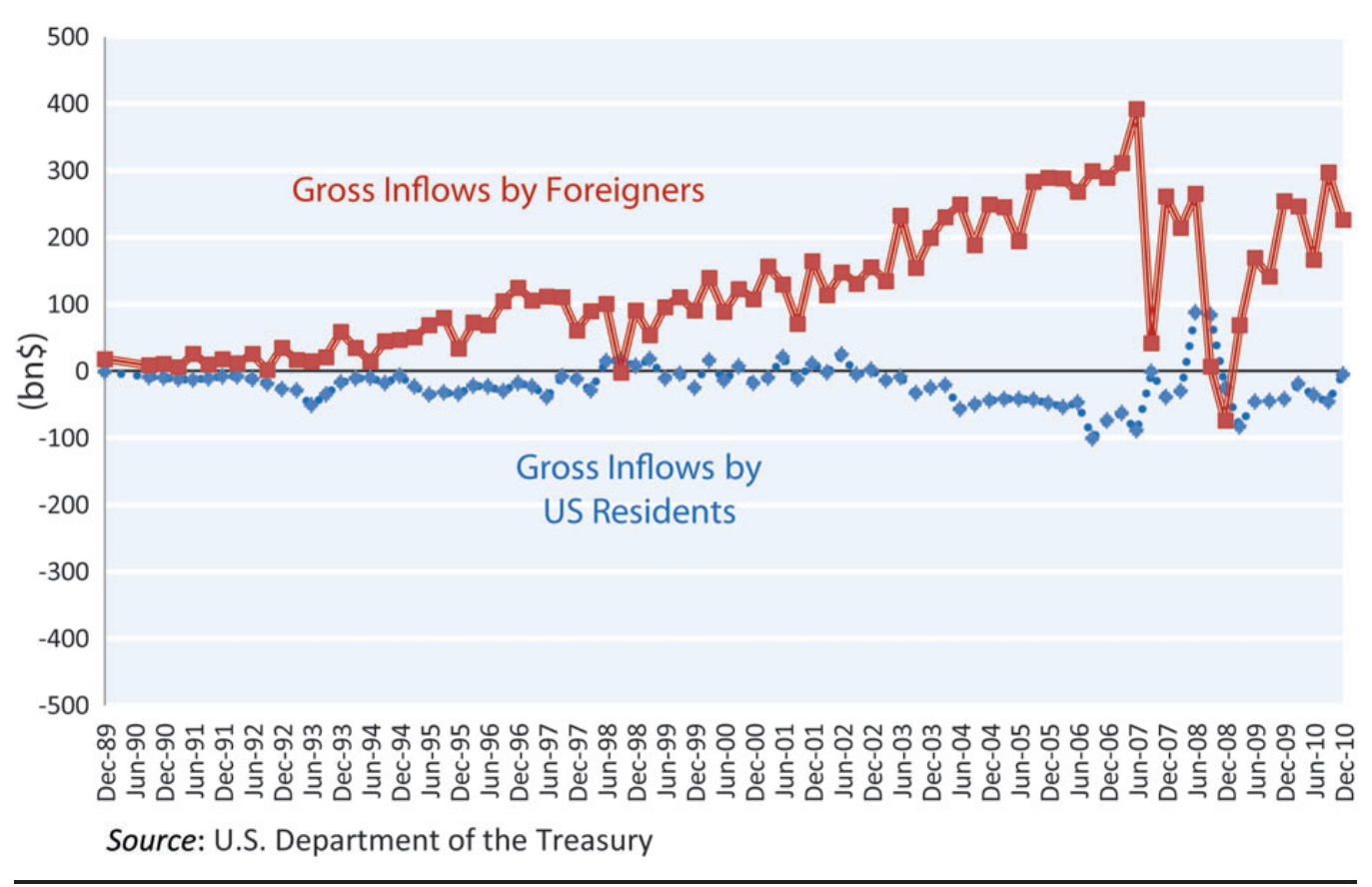

Looking ahead, the global liquidity crisis is likely to further encourage precautionary accumulation of foreign assets by emerging markets. In fact, even at the height of the turmoil, some economies appeared reluctant to deploy their vast reserves for fear of weakening the confidence of international investors (Aizenman and Sun 2009; Aizenman and Hutchison 2010). The experience of these countries in the crisis could prompt them to hold even larger stocks of liquid foreign assets in the future, contributing to the "uphill" pattern of global capital flows.

\section{What Role for Policies?}

Should policies be deployed to eliminate, or at least reduce, global imbalances? In theory, the size or persistence of external imbalances does not provide firm ground for the adoption of policies to reduce them. Theory does not offer clear guidance as to whether a country's current account gap (or global imbalances, more broadly) is sustainable. Theoretical concepts of sustainability typically involve an assessment of whether intertemporal budget constraints are met. Therefore, these concepts raise a timely and important question: "Are deficits today commensurate with eventual future surpluses and capital gains to prevent the economy's net foreign asset position from becoming increasingly negative?" 
In effect, any given current account position can be sustainable, in principle, given sufficient future adjustment. However, the medium- or longer-run sustainability of a country's current account depends on its ability to repay, which, in turn, depends on a host of other factors in addition to current account balances or debt levels.

On conceptual grounds, there is nothing wrong with current account imbalances as long as they reflect socially optimal saving and investment decisions. As noted, in principle, it would be entirely desirable for a country to incur external deficits in the face of productivity improvements or rising future income. Likewise, a country would be well advised to run large external surpluses if it enjoys a large, but temporary, terms-of-trade windfall. However, if saving and investment decisions primarily reflect structural and policy-imposed distortions rather than socially optimal intertemporal choices, then policy action may be warranted (e.g., Blanchard and Milesi-Ferretti 2009).

Examples of such important distortions are the lack of insurance mechanisms at the national or global levels (highlighted in the previous section); inappropriate regulation of the financial system, which most observers place among the key causes of the U.S. bubble-driven overconsumption of the 2000 s and of the ensuing financial crash; or its polar opposite, financial system underdevelopment that contributes to over-saving in emerging markets. In addition, externalities across national economies may make individual countries' imbalances a global (i.e., systemic) concern and justify policy intervention.

In practice, it is often difficult to disentangle the causes of external imbalances. Policy makers may need to take precautionary action even in the absence of a conclusive diagnosis, especially if an abrupt unraveling of the imbalances is likely to entail large costs and create major economic disruption on a national or global scale. Even then, however, intervention should be guided as much as possible by an understanding of the distortions responsible for the socially undesirable pattern of imbalances. The primary objective should be to counter the distortions rather than the imbalances.

The role of domestic distortions is most visible in the cases of China and the United States. For China, there is broad consensus that strengthening the weak social-safety net and developing domestic financial markets should decrease saving rates from their current record highs. Improved coverage and quality of health, pensions, and other social-insurance schemes will reduce households' need for self-insurance through precautionary saving. Indeed, some empirical estimates suggest that the effect could be quantitatively significant. For example, in the case of China, whose initial level of social expenditure is quite low, a 1 percent increase in public social expenditure could lead to a 2 percent decline in household saving, with both expressed as a ratio to GDP (Baldacci et al. 2010). 
The development of domestic financial markets and the enhancement of households and firms' access to finance should likewise reduce private saving, not only in China, but also in other high-saving emerging markets. The relaxation of borrowing constraints lowers households' precautionary savings and the saving for housing purchases and education expenditures. For firms, financial market development reduces the need to retain earnings in anticipation of the potential arrival of good investment projects and might boost aggregate investment by relaxing binding credit constraints on capital expenditures. Overall, the international evidence suggests that the development of financial markets leads to falling saving rates (e.g., Loayza, Schmidt-Hebbel and Servén 2000) and possibly to a (modest) rise in investment rates (OECD 2011), implying an unambiguous decline in the current account surplus (or an increase in the deficit). ${ }^{11}$

In addition to their contribution to narrowing external imbalances, these reforms are likely to have positive effects on welfare and possibly on growth. For example, households' enhanced access to risk-management mechanisms through financial markets and social insurance will likely reduce the variability of their consumption and increase their welfare. In addition, long-run growth should be positively affected by the rise in human capital accumulation associated with improved health and education services and by the improved efficiency in the allocation of investment brought about by financial market development.

Domestic reforms of this type are already underway in China. Recent policy announcements in connection with the Twelfth Five-year Plan anticipate a gradual shift away from the producer-biased growth model of the 2000s toward a more consumption-friendly framework, with higher real wages, increased government social expenditures, and strengthened social-safety nets. ${ }^{12}$ These factors are likely to halt the decline in disposable household income relative to GDP that characterized the last decade and may begin to reduce the incentives for household saving. The declining trend in the ratio of aggregate consumption to GDP that characterized the 2000s appears to have stopped in 2009. Finally, the rise in firm saving is likely to end under the pressure of newly introduced dividend-payment requirements for state-owned enterprises as well as the gradual improvement in access to external financing for investment by private firms.

In the United States, the distortions have been the opposite of those in China. As noted, the private-saving collapse was largely driven by the credit boom and the housing bubble in a context of weak financial regulation. The decrease in household wealth caused by the bursting of the asset bubble and the post-crisis credit contraction have led to an incipient reversal of the steep decline in personal saving, with household saving rates rising by some 2 to 3 percentage points postcrisis. The rising trend is likely to continue in coming years as households partially rebuild their wealth stocks. This process should be helped by reforms underway to strengthen the lax financial-system regulation that fueled the credit and 
consumption boom. However, the scope and effectiveness of such reforms have yet to be established. For the U.S. public sector, the record-high deficits of recent years are set to decline as the crisis-driven fiscal stimulus is gradually phased out. However, the long-term viability of public finances, and thus of external accounts, will remain threatened by another key distortion, the mounting cost of the massively inefficient healthcare system, whose prospects for deep reform remain distant. ${ }^{13}$ This discussion relates to domestic distortions, but global imbalances also reflect systemic distortions, most notably the lack of global insurance mechanisms, which prompts countries to engage in foreign-asset hoarding as self-insurance against external shocks. Self-insurance in the form of low-yield reserve accumulation is costly for the countries involved because it entails major opportunity costs. These costs become considerable when reserve stocks reach their current proportions in emerging markets (e.g., Rodrik 2008).

Precautionary reserve hoarding imposes negative externalities across countries. First, individual countries ignore the fact that their reserve accumulation contributes to depressing the rate of return on reserve assets, adding to the opportunity costs of all other countries. Second, the decline in rates of return on safe assets poses risks for global financial stability because it tends to encourage investor risk taking (the "search for yield") and creates favorable conditions for the emergence of asset bubbles like those at the core of the global crisis (Caballero, Fahri and Gourinchas 2008b). The deterioration in the quality of lenders' portfolios encouraged by cheap funding also makes the economy more vulnerable to adverse shocks (Eden 2012). Paradoxically, this situation amplifies external volatility and prompt additional precautionary hoarding. The implication of these spillover effects is that the self-insurance motive tends to result in the socially excessive accumulation of foreign assets.

The development of global insurance mechanisms offers a more efficient alternative to self-insurance, thus reducing the incentives for the precautionary buildup of foreign reserve stocks (and current account surpluses) in emerging economies. The global crisis has given new impetus to these mechanisms at the global and regional levels. These mechanisms include expanding the IMF's Flexible Credit Line and High-Access Precautionary Arrangement as well as regional currency-swap schemes, such as the Chiang Mai Initiative in East Asia ${ }^{14}$ and bilateral swap arrangements between national monetary authorities and major central banks, such as the Federal Reserve, the European Central Bank, and the Bank of Japan. However, the scale of these mechanisms remains modest, and strong multilateral action to expand them is necessary before they can play a credible risk-management role comparable to that of self-insurance through the hoarding of reserves.

There are other channels through which the external imbalances of some countries could impose negative externalities on others. One channel that is 
frequently mentioned involves the international transmission of financial turbulence. The underlying idea is that global imbalances could trigger a financial crash in a "systemic" deficit country, understood as a large country with extensive financial links with the rest of the world, such as the United States. This situation could arise as the result of a "sudden stop" or as a consequence of the stress placed on the financial system by the intermediation of large capital inflows (e.g., Portes 2009). Either scenario might have severely disruptive effects on other countries through the ripple effects of a collapse in international asset prices in a world ridden with financial frictions. However, these spillover effects are likely to be ignored by domestic authorities when assessing the risks posed by their external gaps and the need for preventive policy action. Thus, individual countries' external imbalances may become "excessive" from a global perspective.

This reasoning sounds persuasive, because the propagation of financial turmoil poses very real dangers to the global economy, as the crisis has clearly shown. However, it is not obvious why external imbalances should make those dangers worse. In particular, the international transmission of asset price shocks is driven by gross cross-border asset positions (e.g., Devereux and Yetman 2010) whereas external imbalances are related to the time path of net foreign asset positions, and the empirical evidence shows that there is no significant link between the trends in gross and net assets (Broner, Lorenzoni, and Schmukler Forthcoming). In addition, history shows a mixed record regarding the unwinding of large global imbalances (Bracke et al. 2008). For example, the Gold Standard episode had a mostly orderly unwinding. In contrast, the imbalances of the 1970s eventually triggered the debt crisis of the 1980s, and the imbalances of the 1980 s led to a mixed outcome; they were followed by a prolonged crisis in the main surplus country (Japan) but had little effect on the main deficit country (the United States).

Negative externalities may also arise from the "export-led" growth strategy followed by some countries, which involves expenditure compression and foreign asset accumulation in support of undervalued real exchange rates-or, equivalently, controls on external borrowing imposed with the same objective (Korinek 2012). In effect, this strategy attempts to divert export demand from competitors and may prompt retaliatory action in a "currency war" of competitive real devaluations that may negatively affect all participants. In fact, a policy of undervaluation is equivalent to the adoption of import tariffs and export subsidies, but these measures represent unfair trade practices under WTO rules, whereas undervaluation does not (Rodrik 2008; Korinek and Servén 2010).

Related to the issue of undervaluation is the adverse spillover from large external surpluses, which arises through their negative contribution to global demand. This adverse spillover is especially a concern in the post-crisis situation, in which global interest rates remain at record lows (Blanchard and Milesi-Ferretti 2011). 
In normal circumstances, a reduction in the investment or an increase in the saving of deficit countries would lead to a reduction in global aggregate demand ex ante, which would be offset ex post by a decline in global interest rates. However, when the world economy is close to a liquidity trap, global interest rates cannot fall further, and the result is a decrease in global demand and output. This outcome could easily be avoided if surplus countries were to raise their aggregate demand. However, this need not be the case: although foreign investors can force deficit countries to adjust by refusing to continue lending to them, markets rarely put pressure on surplus countries (e.g., China) to correct their imbalances. With major industrial countries facing a protracted process of deleveraging and slow growth after the world crisis, demand expansion by surplus emerging markets is likely to be a critical factor in restoring global growth.

These various forms of international spillovers seem to call for multilateral action regarding global imbalances. In truth, however, it is very difficult to gauge their quantitative significance from the perspective of growth or welfare, and the practical challenges involved in multilateral action should not be underestimated. Notwithstanding the qualitative arguments above, it would be exceedingly difficult to establish whether a given deficit or surplus is "excessive" from the global perspective or if a country's depreciated real exchange rate reflects an attempt at unfair competition rather than, for example, a genuine national preference for frugality.

In this context, some current multilateral initiatives (e.g., the G20's "mutual assessment process" or the multilateral surveillance recently entrusted to the IMF) represent efforts to lay the groundwork for consensus guidelines on countries' external balances, exchange rates, foreign assets, and so on. However, it is not clear how much progress they can achieve. In the end, it is unlikely that major countries would agree to set domestic policies (fiscal, monetary, or financial) to maintain their current account balances or real exchange rates to the levels deemed acceptable by other countries. Furthermore, no global governance mechanisms exist to enforce multilateral statements of intention to that effect. The ongoing European crisis shows that collective action can be extremely difficult and complex, even when these mechanisms are present.

In other words, perhaps not too much should be expected from attempts at coordinated rebalancing, aside from the domestic policy actions chosen by individual countries in their own self-interest. Of course, many of the country-level reforms to address domestic distortions, such as those outlined earlier to foster financial system development and social protection in emerging markets and to enhance financial regulation in advanced economies, are steps in the right direction to mitigate the external effects summarized above. However, the extent to which these reforms can achieve a significant, speedy, and sustained correction of global imbalances remains an open question. 


\section{Conclusion}

This paper has reviewed contrasting analytical perspectives in the academic and policy debate on the roots of global imbalances, their likely path in the post-crisis world, and the potential need for policy action to hasten their elimination in the aftermath of the crisis.

Although some observers have argued that the latest episode of global imbalances largely reflects macroeconomic policies and other cyclical factors affecting world goods markets, others hold that the imbalances are primarily driven by an excess global demand for safe assets. The excess demand reflects structural and policy-induced distortions in domestic and global financial markets as well as the action of neo-mercantilist growth strategies. In reality, the evidence suggests that the widening global imbalances of the last decade likely resulted from a combination of both sets of factors.

Global imbalances have narrowed after the crisis under the influence of expansionary demand-management policies in emerging markets as well as the incipient (if modest) rise in U.S. private saving rates. The unwinding of the U.S. fiscal stimulus will likely add to this trend. However, failure to address the domestic and global distortions that, according to the equilibrium view, lie at the root of global imbalances would likely lead to their return. There are reasons to think that excess global demand for quality assets has risen post-crisis as a result of the destruction of previously safe assets - first, with the collapse of mortgage-based securitization and, more recently, with the sovereign debt turmoil in Europe-and to countries' unrelenting demand for self-insurance after the global crash (Caballero 2010). Other things equal, this new surge of global demand for quality assets will likely contribute to the return of global imbalances. Indeed, the incipient return of U.S. capital inflows to their precrisis patterns suggests that this return is already underway.

This paper has reviewed the case for policy action toward the elimination of global imbalances. In principle, current theory offers little guidance to determine what constitutes an excessive current account deficit or surplus. Nevertheless, to the extent that the imbalances reflect structural or policy-induced distortions, actions to remove them are justified from the welfare perspective. However, their primary target would most appropriately be the distortions at work rather than the imbalances themselves, although the magnitude of the latter should decline as a result. A number of domestic policy initiatives recently undertaken in advanced and emerging markets address at major distortions that have direct effects on external imbalances.

Finally, this paper has examined the case for international policy coordination regarding global imbalances. Conceptually, the case for coordination hinges on the existence of negative externalities through which a country's current account 
imbalance imposes costs on other countries. This paper has also reviewed some financial and real mechanisms through which such negative spillovers would likely arise. Because the spillovers are likely to be ignored by individual countries when choosing their own desired current account balances, multilateral policy actions may be warranted. However, the economic significance of these external effects, and thus the potential gains from policy coordination, are, in most cases, difficult to gauge. Moreover, if history is any guide, prospects do not seem promising that major countries would agree to set their macroeconomic policies and structural reforms to maintain their current account balances or real exchange rates at the levels deemed acceptable by other countries. Thus, not too much should be expected from policy coordination. The future of global imbalances is likely to be determined by whatever measures countries decide to adopt in their own self-interests. Whether such measures will result in a significant and sustained narrowing of global imbalances remains to be seen.

\section{Notes}

We are indebted to Ramón Guzmán, Aart Kraay, Anton Korinek, William Martin, Martin Ravallion, Sergio Schmukler, the editor, and three anonymous referees for helpful comments on earlier drafts. We also thank conference participants at the 2010 Meeting of Latin American Economists and seminar participants at the Getulio Vargas Foundation and the Universidad de San Sebastián. Junko Sekine provided able research assistance. Any errors are our own responsibility. The views expressed here are ours alone and do not necessarily reflect those of the World Bank, its Executive Directors, or the countries that they represent.

1. See, e.g., Meissner and Taylor (2006) and Bracke et al. (2008).

2. However, the near balance of the EU's current account, shown in figure 1, conceals a large contrast between Germany, with persistently large current account surpluses, and the rest of the EU, with external deficits in recent years.

3. Thus, East Asia's rising surpluses had initially much more to do with the postcrisis investment slump than with the "saving glut" pointed out in Bernanke (2005). See, for example, Blanchard and Milesi-Ferretti (2009) and Rajan (2010).

4. Eichengreen (2006) and Eichengreen and Park (2006) summarize different views on the causes of global imbalances. The two perspectives highlighted in the text roughly correspond to those outlined by Bracke et al. (2008).

5. This has been termed the "exorbitant duty" of the United States by Gourinchas, Rey, and Govillot (2010), which is the counterpart in crisis times of the "exorbitant privilege" that the United States enjoys in normal times, described earlier in the text.

6. The widening growth differential between emerging and advanced countries, and thus their enhanced role for global growth-what has been recently termed "multipolarity" of the world economy — add to this trend; see Caballero, Fahri and Gourinchas (2008a).

7. There have been numerous empirical assessments of the degree of misalignment of the renminbi. For example, Cline and Williamson (2008) surveyed 18 studies, of which only one concluded that the renminbi was overvalued.

8. Rajan (2010) characterizes the current assignment of roles in the world economy in a similar way, adding the United Kingdom and some smaller EU economies among the "consumers of last 
resort" and defining a third group of emerging markets building large net creditor positions for selfinsurance reasons (see later in the text) or as a result of booming commodity prices (in the case of OPEC and other commodity exporters).

9. This is closely related to the explanations based on asset demand by Mendoza, Quadrini, and Rios-Rull (2009) and Carroll and Jeanne (2009), summarized previously. In both cases, the underlying force is the lack of adequate insurance mechanisms. The main difference is that the focus now is on country-level insurance against external shocks rather than on individual insurance against idiosyncratic shocks.

10. Total gross capital inflows into the United States were likewise dominated by nonofficial flows until 2007; see Borio and Disyatat (2011).

11. Chinn and Ito (2007) argue that the net impact of financial development on the current account depends on the degree of legal development and financial openness. For emerging countries with low levels of legal development and financial openness, financial development may be associated with higher surpluses.

12. In health, for example, reforms were announced in 2009 that aimed to achieve universal and affordable basic health care by 2020. In education, the government introduced a new longterm strategy in 2010 to improve schooling for students under the age of 6 years and over the age of 15 years.

13. In 2011, Medicare and Medicaid, along with Social Security, accounted for 43 percent of the U.S. federal budget. This figure is projected to increase in the future (Congressional Budget Office 2011).

14. The Chiang Mai Initiative is a multilateral currency swap arrangement among the ten members of the Association of Southeast Asia Nations, China (including Hong Kong), Japan and South Korea. This initiative draws from a foreign reserve pool worth US\$120 billion and was launched on March 24, 2010.

\section{References}

Adams, C., and D. Park. 2009. "Causes and Consequences of Global Imbalances: Perspective from Developing Asia." Asian Development Review 26 (1): 19-47.

Aizenman, J., and M. Hutchison. 2010. "Exchange Market Pressure and Absorption by International Reserves: Emerging Markets and Fear of Reserve Loss during the 2008-09 Crisis." NBER Working Paper 16260. National Bureau of Economic Research, Cambridge, MA.

Aizenman, J., and J. Lee. 2007. "International Reserves: Precautionary vs Mercantilist Views." Open Economies Review 18: 191-214.

Aizenman, J., and Y. Sun. 2009. "The Financial Crisis and Sizable International Reserves Depletion: From 'Fear of Floating' to the 'Fear of Losing International Reserves'?" NBER Working Paper 15308. National Bureau of Economic Research, Cambridge, MA.

Angeletos, G. 2007. "Uninsured Idiosyncratic Investment Risk and Aggregate Saving." Review of Economic Dynamics 10 (1): 1-30.

Baldacci, E., G. Callegari, D. Coady, D. Ding, M. Kumar, P. Tommasino, and J. Woo. 2010. "Public Expenditures in Social Programs and Household Consumption in China." IMF Working Paper 10/69. International Monetary Fund, Washington, DC.

Bernanke, B. 2005. "The Global Saving Glut and the U.S. Current Account Deficit." Speech presented at the Sandridge Lecture, Virginia Association of Economics, Richmond, Virginia, March 10, 2005, and the Homer Jones Lecture, St. Speech, Board of Governors of the Federal Reserve System (US). 
Blanchard, O., and G. M. Milesi-Ferretti. 2009. "Global Imbalances: In Midstream?" IMF Staff Position Note SPN/09/29. International Monetary Fund, Washington, DC.

2011. “(Why) Should Current Account Balances Be Reduced?” IMF Staff Discussion Note. International Monetary Fund, Washington, DC.

Borio, C., and P. Disyatat. 2011. "Global Imbalances and the Financial Crisis: Link or No Link." BIS Working Paper 346. Bank for International Settlements, Basel, Switzerland.

Bosworth, B., and S. Collins. 2010. "Rebalancing the U.S. Economy in a Post-Crisis World." ADBI Working Papers No 236. Asian Develpment Bank Institute, Tokyo, Japan.

Bracke, T., M. Bussiere, M. Fidora, and R. Straub. 2008. "A Framework for Assessing Global Imbalances." European Central Bank Occasional Paper 78. Frankfurt am Main, Germany.

Broner, F., G. Lorenzoni, and S. Schmukler. Forthcoming. "Why Do Emerging Economies Borrow Short Term?" Journal of the European Economic Association.

Caballero, R. 2010. "The "Other" Imbalance and the Global Crisis." NBER Working Paper No. 15636. National Bureau of Economic Research, Cambridge, MA.

Caballero, R., E. Farhi, and P. Gourinchas. 2008a. "An Equilibrium Model of Global Imbalances and Low Interest Rates." American Economic Review 98 (1): 358-93.

2008b. "Financial Crash, Commodity Prices, and Global Imbalances.” Brookings Papers on Economic Activity 2008: 1-55.

Carroll, C., and O. Jeanne. 2009. "A Tractable Model of Precautionary Reserves, Net Foreign Assets, or Sovereign Wealth Funds." NBER Working Paper 15228. National Bureau of Economic Research, Cambridge, MA.

Chamon, M., K. Liu, and E. Prasad. 2010. "Income Uncertainty and Household Savings in China." NBER Working Papers 16565. National Bureau of Economic Research, Cambridge, MA.

Chamon, M., and E. Prasad. 2010. "Why are Saving Rates of Urban Households in China Rising?" American Economic Journal: Macroeconomics 2 (1): 93-130.

Chinn, M., and H. Ito. 2007. "Current Account Balances, Financial Development and Institutions: Assaying the World's 'Saving Glut.” Journal of International Money and Finance 26 (4): 546-69.

Cline, W., and J. Williamson. 2008. "Estimates of the Equilibrium Exchange Rate of the Renminbi: Is there a Consensus and if Not, Why Not?" In M. Goldstein and N. Lardy, eds., Debating China's Exchange Rate Policy, 131-54. Washington, DC: Peterson Institute of International Economics.

Congressional Budget Office. 2011. "The Budget and Economic Outlook: Fiscal Years 2011 to 2021." http://www.cbo.gov/publication/21999

Cova, P., M. Pisani, N. Batini, and A. Rebucci. 2008. "Productivity and Global Imbalances: The Role of Non-Tradable Total Factor Productivity in Advanced Economies." IMF Staff Papers 55: $312-25$.

Curcuru, S., C. Thomas, and F. Warnock. 2008. "Current Account Sustainability and Relative Reliability." NBER Working Paper 14295. National Bureau of Economic Research, Cambridge, MA.

De la Torre, A., S. Schmukler, and L. Servén. 2009. "Back to Global Imbalances.” World Bank Research Digest 3 (4): 3-4.

Devereux, M., and A. Sutherland. 2010. "Valuation Effects and the Dynamics of Net External Assets." Journal of International Economics 80 (1): 129-43.

Devereux, M., and J. Yetman. 2010. "Leverage Constraints and the International Transmission of Shocks.” Journal of Money, Credit and Banking 42:71-105.

Dooley, M., D. Folkerts-Landau, and P. Garber. 2004. "The Revived Bretton Woods System: The Effects of Periphery Intervention and Reserve Management on Interest Rates and Exchange Rates 
in Center Countries." NBER Working Paper 10332. National Bureau of Economic Research, Cambridge, MA.

Durdu, C., E. Mendoza, and M. Terrones. 2007. "Precautionary Demand for Foreign Assets in Sudden Stop Economies: An Assessment of the New Mercantilism." Journal of Development Economics 89:194-209.

Eden, M. 2012. "Financial Distortions and the Distribution of Global Volatility." World Bank Policy Research Working Paper 5929. Washington, DC.

Eichengreen, B. 2004. "Global Imbalances and the Lessons of Bretton Woods." NBER Working Paper 10497. National Bureau of Economic Research, Cambridge, MA.

2006. "Global Imbalances: The New Economy, the Dark Matter, the Savvy Investor, and the Standard Analysis.” Journal of Policy Modeling 28:645-52.

Eichengreen, B., and Y. Park. 2006. "Global Imbalances and Emerging Markets." In J.J. Teunissen and A. Akkerman, eds., Global Imbalances and the US Debt Problem: Should Developing Countries Support the US Dollar?, 14-44. The Hague, The Netherlands: Fondad.

Engel, C., and J. Rogers. 2006. "The U.S. Current Account Deficit and the Expected Value of World Output." Journal of Monetary Economics 53:1063-93.

Forbes, K. 2010. "Why do Foreigners Invest in the United States?" Journal of International Economics $80: 3-21$.

Gourinchas, P., and H. Rey. 2007a. "International Financial Adjustment." Journal of Political Economy 26:115.

. 2007b. "From World Banker to World Venture Capitalist: The US External Adjustment and the Exorbitant Privilege.” In R. Clarida, ed., G7 Current Account Imbalances: Sustainability and Adjustment, 11-55. Chicago: University of Chicago Press.

Gourinchas, P., H. Rey, and N. Govillot. 2010. "Exorbitant Privilege and Exorbitant Duty." IMES Discussion Paper Series number 10-E-20. Institute for Monetary and Economic Studies, Tokyo, Japan.

Habib, M. 2010. "Excess Returns on Net Foreign Assets: The Exorbitant Privilege from a Global Perspective.” European Central Bank Working Paper 1158. Frankfurt am Main, Germany.

Hausmann, R., and F. Sturzenegger. 2006. "Global Imbalances or Bad Accounting?: The Missing Dark Matter in the Wealth of Nations." Working Paper No. 124. Center for International Development, Harvard University, Cambridge, MA.

Jeanne, O., and R. Ranciere. 2011. "The Optimal Level of International Reserves for Emerging Market Countries: A New Formula and Some Applications.” Economic Journal 121:905-30.

Korinek, A. 2012. "Capital Controls and Currency Wars.” Working Paper. University of Maryland, College Park, MD.

Korinek, A., and L. Servén. 2010. "Undervaluation through Foreign Reserve Accumulation: Static Losses, Dynamic Gains.” World Bank Policy Research Working Paper 5250. Washington, DC.

Kraay, A., N. Loayza, L. Servén, and J. Ventura. 2005. "Country Portfolios.” Journal of the European Economic Association 3:914-45.

Kraay, A., and J. Ventura. 2005. "The Dot-Com Bubble, the Bush Deficits, and the US Current Account." NBER Working Paper No. 11543. National Bureau of Economic Research, Cambridge, MA.

Laibson, D., and J. Mollerstrom. 2010. "Capital Flows, Consumption Booms and Asset Bubbles: A Behavioural Alternative to the Savings-Glut Hypothesis.” NBER Working Paper 15759. National Bureau of Economic Research, Cambridge, MA. 
Loayza, N., K. Schmidt-Hebbel, and L. Servén. 2000. "What Drives Private Saving Across the World?" Review of Economics and Statistics 82:165-81.

Meissner, C., and A. Taylor. 2006. "Losing our Marbles in the New Century?: The Great Rebalancing in Historical Perspective." NBER Working Paper 12580. National Bureau of Economic Research, Cambridge, MA.

Méjean, I., P. Rabanal, and D. Sandri 2011. "Current Account Rebalancing and Real Exchange Rate Adjustment between the U.S. and Emerging Asia." IMF Working Paper 11/46. International Monetary Fund, Washington, DC.

Mendoza, E., V. Quadrini, and J. Rios-Rull. 2009. "Financial Integration, Financial Deepness and Global Imbalances.” Journal of Political Economy 117:371-416.

Mussa, M. 2004. "Exchange Rate Adjustments Needed to Reduce Global Payments Imbalances." In C.F. Bergsten and J. Williamson, eds., Dollar Adjustment: How Far? Against What?, 113-38. Washington, DC: Institute for International Economics.

Obstfeld., M., and K. Rogoff. 2007. "The Unsustainable U.S. Current Account Position, Revisited.” In R.H. Clarida, ed., G7 Current Account Imbalances: Sustainability and Adjustment, 339-376. Cambridge, MA: National Bureau of Economic Research.

2009. "Global Imbalances and the Financial Crisis: Products of a Common Cause." Discussion Papers 7606. Center for Economic and Policy Research, London, UK.

OECD 2011. "The Impact of Structural Reforms on Current Account Imbalances." OECD Economics Department Policy Notes No. 3. Organisation for Economic Co-operation and Development, Paris, France.

Portes, R. 2009. "Global Imbalances.” In M. Dewatripont, X. Freixas, and R. Portes, eds., Macroeconomic Stability and Financial Regulation, 19-26. London, UK: Center for Economic and Policy Research.

Prasad, E. 2011. "Rebalancing Growth in Asia." International Finance 14 (1): 27-66.

Rajan, R. 2010. Fault Lines. Princeton, NJ: Princeton University Press.

Rodrik, D. 2008. "The Real Exchange Rate and Economic Growth.” Brookings Papers on Economic Activity 2008:365-412.

Roubini, N. 2008. "Will the Bretton Woods 2 (BW2) Regime Collapse Like the Original BrettonWoods Regime Did? The Coming End Game of BW2." http://www.economonitor.com/ nouriel/2008/07/06/will-the-bretton-woods-2-bw2-regime-collapse-like-the-original-bretton-woodsregime-did-the-coming-end-game-of-bw2/

Sandri, D. 2010. "Growth and Capital Flows with Risky Entrepreneurship." IMF Working Paper WP/10/37. International Monetary Fund, Washington, DC.

Taylor, J. 2009. Getting Off Track. Stanford, CA: Hoover Institution Press. 